\title{
Review
}

\section{Nicotinic acetylcholine receptor-mediated calcium signaling in the nervous system}

\author{
Jian-xin SHEN ${ }^{1,2, *}$, Jerrel L YAKEL $L^{1, *}$ \\ ${ }^{1}$ Laboratory of Neurobiology (LN), National Institute of Environmental Health Sciences (NIEHS), National Institutes of Health (NIH), Department of \\ Health and Human Services (DHHS), PO Box 12233, Research Triangle Park (RTP), NC 27709, USA; ${ }^{2}$ Shantou University Medical College, Shantou \\ 515041, China
}

\begin{abstract}
Based on the composition of the five subunits forming functional neuronal nicotinic acetylcholine receptors (nAChRs), they are grouped into either heteromeric (comprising both a and $\beta$ subunits) or homomeric (comprising only a subunits) receptors. The nAChRs are known to be differentially permeable to calcium ions, with the a7 nAChR subtype having one of the highest permeabilities to calcium. Calcium influx through nAChRs, particularly through the a-bungarotoxin-sensitive a7-containing nAChRs, is a very efficient way to raise cytoplasmic calcium levels. The activation of nAChRs can mediate three types of cytoplasmic calcium signals: (1) direct calcium influx through the nAChRs, (2) indirect calcium influx through voltage-dependent calcium channels (VDCCs) which are activated by the nAChR-mediated depolarization, and (3) calciuminduced calcium release (CICR) (triggered by the first two sources) from the endoplasmic reticulum (ER) through the ryanodine receptors and inositol $(1,4,5)$-triphosphate receptors $\left(\mathrm{IP}_{3} \mathrm{Rs}\right)$. Downstream signaling events mediated by nAChRmediated calcium responses can be grouped into instantaneous effects (such as neurotransmitter release, which can occur in milliseconds after nAChR activation), short-term effects (such as the recovery of $n A C h R$ desensitization through cellular signaling cascades), and long-term effects (such as neuroprotection via gene expression). In addition, nAChR activity can be regulated by cytoplasmic calcium levels, suggesting a complex reciprocal relationship. Further advances in imaging techniques, animal models, and more potent and subtype-selective ligands for neuronal nAChRs would help in understanding the neuronal nAChR-mediated calcium signaling, and lead to the development of improved therapeutic treatments.
\end{abstract}

Keywords: nicotinic acetylcholine receptors; calcium; cellular signaling; nervous system

Acta Pharmacologica Sinica (2009) 30: 673-680; doi: 10.1038/aps.2009.64; published online 18 May 2009

\section{Introduction}

Neuronal nicotinic acetylcholine (ACh) receptors (nAChRs) are in the cys-loop ligand-gated ion channel superfamily, and are activated by nicotine in addition to the endogenous neurotransmitter ACh. The nAChRs are widely expressed in the brain, located both at the synapse (presynaptically and postsynaptically) as well as extrasynaptically ${ }^{[1,2]}$. Presynaptic and preterminal nAChRs can enhance neurotransmitter release, postsynaptic nAChRs can contribute to fast excitatory transmission, and extrasynaptic nAChRs can modulate many neurotransmitter systems by influencing neuronal excitability and/or intracellular

\footnotetext{
* Correspondence to Dr Jerrel L YAKEL or Dr Jian-xin SHEN. E-mail: yakel@niehs.nih.gov or shenj2@niehs.nih.gov Received 2009-02-12 Accepted 2009-04-14
}

processes ${ }^{[1-3]}$. The nAChRs play important modulatory roles in neuronal development and synaptic plasticity, participating in cognitive functions such as learning, memory, and attention. In addition, decrease, disruption or alteration in the function of neuronal nAChRs contributes to dysfunctions associated with various neurodegenerative diseases and disorders, including (but not limited to) epilepsy, schizophrenia, Parkinson's disease, autism, Alzheimer's disease, and addiction $^{[1,4]}$.

Neuronal $n A C h R s$ are pentameric transmembrane proteins, consisting of five subunits from a portfolio of nine $\alpha(\alpha 2-\alpha 10)$ and three $\beta(\beta 2-\beta 4)$ subunits $^{[5-7]}$. Some are homomeric nAChRs, such as $\alpha 7$ receptors which contain five $\alpha 7$ subunits, and others are heteromeric nAChRs, which comprise $\alpha$ and $\beta$ subunits ${ }^{[1]}$. Different subtypes of neuronal $\mathrm{nAChRs}$ are known to be differentially permeable to calcium ions $\left(\mathrm{Ca}^{2+}\right)^{[2,3,8]}$. The $a 7 \mathrm{nAChR}$ subtype has one of the 
highest permeabilities to calcium ${ }^{[7]}$, the activation of which can raise cytoplasmic calcium levels and trigger a series of calcium-dependent intracellular processes. Calcium ions are one of the most versatile intracellular messengers known, and impacts almost every aspect of cellular life, including excitability, exocytosis, motility, apoptosis, and transcription; this is achieved by interacting with thousands of proteins and their downstream effectors ${ }^{[9,10]}$. Calcium influx through nAChRs, particularly through the $\alpha$-bungarotoxin-sensitive $\alpha 7$-containing $\mathrm{nAChRs,}$ is a very efficient way to raise cytoplasmic calcium levels. Here we will present a brief summary of the calcium signals initiated by the activation of neuronal nAChRs, and its possible physiological relevance.

\section{Cytoplasmic calcium signals initiated by neuronal nAChR activation}

There are three types of cytoplasmic calcium signals initiated by neuronal $\mathrm{nAChR}$ activation; (1) direct calcium influx through the $\mathrm{nAChR}{ }^{[6,11]},(2)$ indirect calcium influx through voltage-dependent calcium channels (VDCCs) which are activated by the nAChR-mediated depolarization ${ }^{[6,11]}$, and (3) calcium-induced calcium release (CICR) (triggered by the two sources listed above) from the endoplasmic reticulum (ER) through the ryanodine receptors ${ }^{[12-14]}$ and inositol $(1,4,5)$-triphosphate receptors $\left(\mathrm{IP}_{3} \mathrm{Rs}\right)^{[13-15]}$.

Direct calcium influx through nAChRs Two primary methods have been developed for estimating the calcium permeability of nAChRs. The first utilizes the shift in the reversal potential of nAChR-mediated currents due to changes in the extracellular calcium concentration. The permeability ratio $\mathrm{PCa} / \mathrm{PNa}$, which is the relative permeability of calcium to sodium ions, was then estimated using the Goldmann-Hodgkin-Katz constant field equation ${ }^{[16,17]}$. The $\mathrm{PCa} / \mathrm{PNa}$ ratio estimated in this way was $\sim 2$ for heteromeric neuronal non- $\alpha 7$ nAChRs, and $>10$ for homomeric $\alpha 7$ or the heteromeric $\alpha 9 / \alpha 10 \mathrm{nAChRs}{ }^{[2,3,7,8]}$. However, this relative approach has serious limitations.

The second method for estimating the calcium permeability of nAChRs is based on fluorescent calcium indicators ${ }^{[7,18-20]}$. This approach relies on the simultaneous recording of fluorescence signals and transmembrane currents, and requires perfect voltage control of the cell and the absence of CICR. In this way, the percentage of the total current flowing through a given ion channel that is carried by calcium ions, the so-called "fractional calcium current" (usually indicated as Pf), can be measured. Heteromeric neuronal nAChRs have a Pf of $2 \%-5 \%$, whereas homomeric $\alpha 7 \mathrm{nAChRs}$ (which have the highest Pf) range from 6\%-12\% (depending on the species) $)^{[7,21]}$.

Interestingly, for the $\alpha 3$ subunit-containing human nAChRs, incorporation of the $\alpha 5$ subunit significantly increases calcium permeability ${ }^{[22]}$. Populations of nAChRs composed of $\alpha 4$ and $\beta 2$ subunits with different stoichiometries can be expressed in oocytes with different functional properties; eg the $(\alpha 4)_{3}(\beta 2)_{2}$ stoichiometry has been demonstrated to have a much greater $\mathrm{Ca}^{2+}$ permeability than does the $(\alpha 4)_{2}(\beta 2)_{3}$ stoichiometry $^{[23]}$.

Indirect calcium influx through VDCCs Activation of nAChRs can depolarize neurons, inducing the activation of the VDCCs and subsequent calcium influx. The nAChRs that contain $\alpha 3$ and/or $\beta 2$ subunits in brain and ganglionic neuronal preparations are associated predominantly with calcium signals that are mediated by depolarization and the activation of $\operatorname{VDCCs}^{[12,14,24]}$, as well as the $\alpha 7$ $n A C h R s^{[25,26]}$. Calcium influx through VDCCs augments the primary calcium signals generated by the direct influx through $\mathrm{nAChRs} s^{[11,14]}$. These two mechanisms may be physiologically complementary; calcium entry through inwardly rectifying $\mathrm{nAChRs}$ will be robust under either resting or hyperpolarized potentials, whereas calcium influx through VDCCs will occur mainly at more depolarized potentials $(-40 \mathrm{mV})^{[27]}$.

Intracellular calcium release from internal stores In addition to the entry of extracellular calcium through channels in the plasma membrane, the cytoplasmic concentration of calcium reflects a complex interplay between buffering and mobilization capacities. In particular, calcium release from intracellular stores (via CICR) can have a crucial role in defining calcium responses ${ }^{[28]}$. The activation of $\alpha 7 \mathrm{nAChRs}$ can generate calcium transients via entry through the channel pore itself (independently of VDCCs), which can then activate CICR from ryanodine-dependent stores ${ }^{[12-14]}$. In neurons of the substantia nigra pars compacta, depletion of internal calcium stores inhibits the increase in cytoplasmic calcium levels induced by nicotine and the $\alpha 7 \mathrm{nAChR}$-selective agonist choline ${ }^{[12]}$. Blockade of ryanodine receptors in neuroblastoma cells also significantly reduces the increase in cytoplasmic calcium induced by activation of $\beta 2$ and $\alpha 7$ subunit-containing $n A C h R s^{[14]}$. Functional coupling between a $7 \mathrm{nAChRs}$ and ryanodine receptors has also been observed in cultured hippocampal astrocytes, where $\alpha 7 \mathrm{nAChR}$ mediated calcium signals arise primarily from CICR through ryanodine receptors ${ }^{[13]}$.

Cytoplasmic calcium signals can also be enhanced by activation of the $\mathrm{IP}_{3}$ receptor $\left(\mathrm{IP}_{3} \mathrm{R}\right)$ second-messenger system and the subsequent release of calcium from intracellular stores. The involvement of $\mathrm{IP}_{3} \mathrm{R}$-dependent calcium stores 
in neuronal $\mathrm{nAChR}$ signaling was shown when $\mathrm{nAChR}$ induced calcium responses were reduced with $\mathrm{IP}_{3} \mathrm{R}$-selective antagonists ${ }^{[13-15]}$. The functional interaction between $\mathrm{IP}_{3}$ and ryanodine receptor-dependent calcium signals is considered to be a key signaling mechanism ${ }^{[28]}$. Reports that nAChRinduced release of calcium from $\mathrm{IP}_{3} \mathrm{Rs}$ is secondary to that from ryanodine receptors are consistent with their sequential activation $^{[13,14]}$. Although it is unclear how $\mathrm{nAChR}$ stimulation activates $\mathrm{IP}_{3} \mathrm{Rs}$, possible mediators are a calcium-dependent phospholipase $\mathrm{C}(\mathrm{PLC})^{[29]}$, and/or calcium-sensor proteins ${ }^{[30]}$ activated following $\mathrm{nAChR}$ activation. The ability to activate different sources of calcium confers a further spatial and temporal dimension to the calcium signals evoked by $\mathrm{nAChR}$ activation. By converting acute $\mathrm{nAChR}$ stimulation into sustained cellular events, calcium signals may be a crucial link between $\mathrm{nAChRs}$ and the downstream processes that impinge on many neuronal functions.

Another source of intracellular $\mathrm{Ca}^{2+}$ stores includes the mitochondria ${ }^{[31]}$. The ER-mitochondrial interactions are important for the continued filling of the $\mathrm{ER}^{[32,33]}$. The efflux of $\mathrm{Ca}^{2+}$ from the mitochondria through the mitochondrial $\mathrm{Na}^{+} / \mathrm{Ca}^{2+}$ exchanger can contribute to the overfilling of some intracellular $\mathrm{Ca}^{2+}$ stores, particularly those that are in extremely close proximity to mitochondria ${ }^{[34,35]}$. The repeated activation of $\mathrm{nAChRs}$ can enhance calcium release from mitochondria ${ }^{[36,37]}$.

\section{Downstream signaling events mediated by nAChR- mediated calcium responses}

Calcium signals initiated by the activation of $\mathrm{nAChRs}$ can initiate responses via a variety of different mechanisms. According to the duration and timing, we have grouped these into instantaneous effects, short-term effects, and long-term effects.

\section{Instantaneous effects}

Regulation of cytoplasmic calcium levels The immediate impact of $\mathrm{nAChR}$ activation is the direct influx of cations (including calcium ions) through the channel pore. This instantaneous membrane depolarization can then activate the VDCCs, thereby increasing cytoplasmic calcium levels. Both the direct calcium influx through $\mathrm{nAChRs,} \mathrm{and} \mathrm{indirect}$ calcium influx through VDCCs, can then trigger calcium release from intracellular calcium stores as noted above ${ }^{[6]}$. In chick ciliary ganglion neurons, a major portion of the $\mathrm{nAChR}$-induced changes in cytoplasmic calcium levels is due to influx through VDCCs ${ }^{[11,26]}$. In cultured hippocampal neurons, about $85 \%$ of the nAChR-mediated calcium level changes were blocked by cadmium, a VDCC blocker, suggesting that most of the calcium influx was through VDCCs $^{[25]}$. In cultured hippocampal astrocytes ${ }^{[13]}$, activation of $\mathrm{nAChRs}$ leads to a rapid and large calcium transient. This rise in cytoplasmic calcium level is entirely dependent on direct calcium influx, without any contribution from VDCC activation.

Regulation of neurotransmitter release At presynaptic terminals, the activation of $\mathrm{nAChRs}$ can initiate neurotransmitter release directly by raising intraterminal calcium levels due to calcium influx through the channel pore, as well as indirectly by calcium influx through VDCC activation due to membrane depolarization. For example, in hippocampal synaptosomes, the activation of $\alpha 3 \beta 4 \mathrm{nAChRs}$ induced the release of noradrenaline without the involvement of $\mathrm{VDCCs}^{[38]}$, whereas in striatal dopamine synaptosomes with $\beta 2$ subunit-containing $\mathrm{nAChRs}{ }^{[39]}$, the $\mathrm{nAChR}$-induced release of dopamine was mediated by VDCCs ${ }^{[38,40]}$. In addition, presynaptic $\alpha 7 \mathrm{nAChRs}$ at excitatory synapses can increase the probability of glutamate release in the presence of tetrodotoxin and cadmium ${ }^{[41]}$. Lastly in hippocampal mossy fiber terminals, calcium entry through a $7 \mathrm{nAChRs}$ can initiate CICR from presynaptic stores, and elicit bursts of miniature excitatory postsynaptic currents ${ }^{[42]}$. All of these examples of calcium-dependent neurotransmitter release facilitated by presynaptic nAChRs are consistent with the activation of exocytotic mechanisms ${ }^{[43]}$.

Short-term effects Although electrical signaling and neurotransmitter release related to $\mathrm{nAChR}$ activation can occur within milliseconds, downstream events and regulatory feedback mechanisms operate over longer time periods, often requiring seconds to minutes ${ }^{[4]}$. These events usually depend on cellular signaling without gene expression, and we will refer to these as 'short-term effects'.

Regulation of neurotransmitter release In addition to inducing neurotransmitter release as noted above, presynaptic $\mathrm{nAChR}$ may also modulate transmitter release through calcium-mediated signal transduction cascades. For example, protein kinase $\mathrm{C}(\mathrm{PKC})$ has been proposed to modulate striatal dopamine release by $\mathrm{nAChR}$ activation ${ }^{[44]}$. Furthermore, $\mathrm{nAChR}$ and PKC-mediated stimulation of extracellular signal-regulated mitogen-activated protein kinase $(\mathrm{ERK} / \mathrm{MAPK})^{[45]}$ and annexin phosphorylation ${ }^{[46]}$ have been reported to contribute to the regulation of exocytosis in adrenomedullary cells.

Regulation of $n A C h R$ desensitization The $\mathrm{nAChRs}$ can undergo desensitization, a reversible reduction in response during sustained agonist application, which has been proposed to be important in controlling synaptic efficacy, responses to cholinergic agents, and certain nAChR-related 
disease states ${ }^{[47]}$. For $\alpha 7$-containing nAChRs in rat hippocampal interneurons ${ }^{[48]}$, and for native nAChRs in chromaffin cells ${ }^{[49,50]}$, the recovery from desensitization is delayed by high cytoplasmic calcium levels. This is probably because calcium catalyzes the activity of enzymes such as protein kinase $\mathrm{C}$ (PKC) and/or calcineurin, whose dynamic balance controls the recovery process ${ }^{[47]}$. In addition, $\alpha 7 \mathrm{nAChRs}$ on chick ciliary ganglion neurons can undergo substantial activity-dependent inactivation ${ }^{[4,51]}$; this inactivation or rundown depends on receptor activation, calcium influx, calcium release from internal stores, calmodulin, and CaMKII activity.

Long-term effects A critical element of the long-term consequence of the regulation of synaptic signaling at the cellular level is probably that of transcriptional regulation. In addition to influencing neurotransmitter release, a role for $\mathrm{nAChRs}$ in the regulation of cell signaling and gene expression has been reported ${ }^{[52]}$. In neuroblastoma cells, exposure to nicotine influences the expression of a diverse set of genes, including transcription and protein-processing factors, and proteins associated with RNA binding and the plasma membrane ${ }^{[53]}$. For nAChRs, such transcriptional control is usually triggered by calcium influx directly through the receptors, indirectly through VDCCs, and through release from internal stores ${ }^{[4,54-58]}$.

Regulation of neurotransmitter release The activation of $n A C h R s$ can influence gene expression for immediate early genes and genes involved in transmitter synthesis ${ }^{[15,52,59,60]}$. In the chick ciliary ganglion ${ }^{[61]}$, the nAChR-mediated control of transcription relies on calcium influx and calcium release from internal stores to activate first CaMKII/IV, and then ERK/MAPK. These enzymes activate the transcription factor CREB (the cAMP response element-binding protein), which can alter gene expression.

As the rate-limiting step in catecholamine biosynthesis, tyrosine hydroxylase $(\mathrm{TH})$ is a major control point in neurotransmitter release from catecholamine-containing neurons, and is subject to diverse regulatory mechanisms ${ }^{[62]}$. Long-term treatment with nicotine increases the concentration of TH-mRNA and, consequently, TH-activity, both in vivo and in chromaffin cells ${ }^{[62]}$. This effect is calcium-dependent and mediated by protein kinase $A(P K A)^{[63]}$. The nicotine-induced activation of expression of the gene encoding $\mathrm{TH}$ requires a prolonged increase in calcium concentration, and the activation of store-dependent calcium channels ${ }^{[63]}$ and $\mathrm{ERK} / \mathrm{MAPK}^{[64]}$.

Involvement in synaptic plasticity and memory mechanisms Agonists and antagonists of $\mathrm{nAChRs}$ can improve and impair performance in cognitive tasks, respectively ${ }^{[65]}$. However, elucidating the cellular mechanisms that underlie the contribution of $\mathrm{nAChRs}$ to cognitive function is a daunting task. CREB and ERK/MAPK signaling cascades have attracted particular attention because their activities are central to long-term plasticity in the nervous system ${ }^{[66]}$. This might have physiological relevance to many functions, including (but not limited to) addiction, learning and memory ${ }^{[67]}$. The nAChRs mediate the calcium-dependent activation of ERK/MAPK and CREB in several neuronal models ${ }^{[61,68,69]}$. The hippocampus has received particular attention as a key area for memory processing, and $\mathrm{nAChR}$-mediated intracellular calcium increases promote activation of CaMKII/ IV and ERK/MAPK, and the sustained phosphorylation of $\mathrm{CREB}^{[69,70]}$. In addition, in rat brain slices that contain both the ventral tegmental area (VTA) and the nucleus accumbens (NAc), it has been demonstrated ${ }^{[71]}$ that activation of presynaptic $\alpha 7 \mathrm{nAChRs}$ induces long-term potentiation (LTP; a putative cellular model for learning and memory) of the excitatory input to the VTA if nicotine application is paired with postsynaptic stimulation. In hippocampal preparations, presynaptic $\alpha 7 \mathrm{nAChRs}$ are found to enhance the probability of $\mathrm{LTP}^{[72]}$. These actions might also contribute to the mechanisms that underlie the effects of nicotine on cognition. Activation of the hippocampal ERK/MAPK pathway is required for the formation of contextual and spatial memories in mammals ${ }^{[66]}$. Thus, factors that interfere with the activation of this pathway by $\alpha 7 \mathrm{nAChRs}$ might contribute to cognitive decline.

Involvement in reward and dependence Drug dependence is thought to involve plastic changes in neuronal circuits that are associated with 'rewarding' behaviours. Nicotine dependence, which is mediated by interaction with nAChRs, is likely to involve the modification of signaling cascades that modulate synaptic plasticity and gene expression, as proposed for other drugs of abuse ${ }^{[67,73,74]}$. Like other addictive substances and rewarding behaviours, nicotine increases the release of dopamine from the mesolimbic projections to the $\mathrm{NAc}^{[6,75]}$. Although somatodendritic $\mathrm{nAChRs}$ on dopaminecontaining neurons of the VTA can excite these neurons directly, which results in transient responses that are terminated by desensitization of $\mathrm{nAChRs}{ }^{[76]}$, the stimulation and subsequent desensitization of GABA-containing neurons in the VTA also contributes to an excitatory effect through removal of the inhibitory influence of $\mathrm{GABA}^{[77]}$.

For nicotine addiction, studies show that in rats, nicotine withdrawal (but not chronic treatment with nicotine itself) significantly reduced the levels of CREB and phosphorylated CREB in rat cortex and the amygdala ${ }^{[78]}$. Phosphorylated CREB also decreased in the NAc in mice following chronic 
consumption of nicotine in their drinking water ${ }^{[79]}$. Changes in phosphorylated CREB in the NAc are consistent with previous reports that decreased CREB activity in this region contributes to drug reinforcement ${ }^{[80]}$.

Involvement in neuroprotection Nicotine and other $\mathrm{nAChR}$ agonists are neuroprotective in several models of neuronal death, both in vivo and in vitro ${ }^{[81]}$. The nAChRmediated neuroprotection against excitotoxicity is calciumdependent ${ }^{[82-84]}$ and does not involve blockade of glutamate receptor function ${ }^{[83-85]}$. Excessive activation of the $\mathrm{N}$-methyl-D-aspartate (NMDA) receptor is thought to play a prominent role in a variety of acute and chronic neurological injuries ${ }^{[86,87]}$. In hippocampal slices, nicotine-mediated protection against acute NMDA excitotoxicity is mediated by the activation of phosphatidylinositol 3-kinase $\left(\mathrm{PI}_{3} \mathrm{~K}\right)$ and the ERK/MAPK pathway ${ }^{[84]}$. These signalling molecules could increase the expression of calcium buffering proteins such as calbindin-D28K, which have been implicated in the nAChR-dependent amelioration of excitotoxic insults ${ }^{[85]}$. In cortical cultures, the nicotine-induced calcium-dependent activation of the phosphatase calcineurin is proposed to mediate the protection afforded by nicotine against glutamate excitotoxicity ${ }^{[88]}$.

\section{Perspectives}

Compared to the rapid nAChR-mediated current, the corresponding kinetics of the intracellular calcium response are relatively slow; eg the time-to-peak for nAChR-mediated current responses in dendrites of interneurons was $39 \mathrm{~ms}$, whereas the duration of the calcium response was $7 \sec ^{[3]}$. In general, the prolonged duration of the evoked $\mathrm{Ca}^{2+}$ response by $\mathrm{nAChR}$ stimulation is due to several factors, including (but not limited to) the fact that the intracellular removal mechanisms for calcium are slower, and the secondary $\mathrm{Ca}^{2+}$ release from intracellular stores (eg, the ER and mitochondria) or from the extracellular space via VDCC activation. Thus the relatively large and prolonged $\mathrm{Ca}^{2+}$ accumulation mediated by nAChRs helps these "fast" receptors create prolonged responses at the level of $\mathrm{Ca}^{2+}$ homeostasis ${ }^{[3]}$.

The direct and indirect calcium influx resulting from the activation of neuronal nAChRs can generate specific, complex calcium signals that mediate instantaneous (such as presynaptic neurotransmitter release), short-term (such as the modulation of desensitization through cellular signaling) and long-term effects (such as neuroprotection via gene expression). The regulation of calcium signaling is one of the most important aspects induced by the activation of neuronal $\mathrm{nAChRs}{ }^{[6]}$, which are cell-type, location, and receptor subtype-specific. However the spatial and temporal characteristics of nAChR-mediated calcium signaling are far from understood. In addition, $\mathrm{nAChR}$ activity can be regulated by cytoplasmic calcium levels ${ }^{[48,89,90]}$, suggesting a complex reciprocal relationship. Consistent with this, we recently found that the activation of the $M_{1}$ muscarinic ACh receptor in hippocampal interneurons decreased the function of the $\alpha 7 \mathrm{nAChRs}$ in a calcium-dependent manner ${ }^{[89]}$.

Physiological roles for neuronal nAChRs continue to be delineated. For example the functions of nAChRs on glia, especially on astrocytes, which occupy about half of the total volume of the brain and are critical for understanding the full picture of various brain functions ${ }^{[91,92]}$, have received considerably less attention to date than for receptors expressed in neurons. However evidence suggests that astrocytic nAChRs may be involved in neuroprotection. Furthermore there may be a role for $\mathrm{nAChRs}$ in inflammatory responses in the brain as in the periphery ${ }^{[93-95]}$. The identification of novel gene targets regulated by neuronal $\mathrm{nAChR}$ function remains a big challenge, requiring the continued elucidation of the signaling pathways through which nAChRs regulate their expression. The ERK/MAPK signaling cascade is considered to lie at the center of many signaling pathways, and so a particular association with $\alpha 7 \mathrm{nAChRs}$ in relation to long-term behavioural changes is still waiting to be addressed ${ }^{[6]}$.

Although the intracellular mechanism that mediate the modulation of neuronal nAChRs are not fully resolved, further advances in imaging techniques, animal models, and more potent and subtype-selective ligands for nAChRs would almost certainly help in understanding the neuronal $\mathrm{nAChR}$-mediated calcium signaling and lead to better therapeutic treatments.

\section{Acknowledgements}

We would like to thank S DUDEK and S B SIMONS for advice in preparing the manuscript. Research was supported by the Intramural Research Program of the NIH, National Institute of Environmental Health Sciences; the National Natural Science Foundation of China (№ 30470900), Natural Science Foundation of Guangdong Province (№ 04020253) and SRF for ROCS, SEM.

\section{References}

1 Dani JA, Bertrand D. Nicotinic acetylcholine receptors and nicotinic cholinergic mechanisms of the central nervous system. Annu Rev Pharmacol Toxicol 2007; 47: 699-729.

2 McKay BE, Placzek AN, Dani JA. Regulation of synaptic 
transmission and plasticity by neuronal nicotinic acetylcholine receptors. Biochem Pharmacol 2007; 74: 1120-33.

3 Szabo SI, Zelles T, Lendvai B. Intracellular $\mathrm{Ca}^{2+}$ dynamics of hippocampal interneurons following nicotinic acetylcholine receptor activation. Neurochem Int 2008; 52: 135-41.

4 Berg DK, Conroy WG. Nicotinic alpha 7 receptors: synaptic options and downstream signaling in neurons. J Neurobiol 2002; 53: 512-23.

5 Champtiaux N, Gotti C, Cordero-Erausquin M, David DJ, Przybylski C, Lena C, et al. Subunit composition of functional nicotinic receptors in dopaminergic neurons investigated with knock-out mice. J Neurosci 2003; 23: 7820-9.

6 Dajas-Bailador FA, Wonnacott S. Nicotinic acetylcholine receptors and the regulation of neuronal signalling. Trends Pharmacol Sci 2004; 25: 317-24.

7 Fucile $\mathrm{S}$. $\mathrm{Ca}^{2+}$ permeability of nicotinic acetylcholine receptors. Cell Calcium 2004; 35: 1-8.

8 Fayuk D, Yakel JL. Dendritic $\mathrm{Ca}^{2+}$ signalling due to activation of alpha7-containing nicotinic acetylcholine receptors in rat hippocampal neurons. J Physiol 2007; 582: 597-611.

9 Cheng H, Lederer WJ. Calcium sparks. Physiol Rev 2008; 88: 1491-545.

10 Clapham DE. Calcium signaling. Cell 2007; 131: 1047-58.

11 Rathouz MM, Berg DK. Synaptic-type acetylcholine receptors raise intracellular calcium levels in neurons by two mechanisms. J Neurosci 1994; 14: 6935-45.

12 Tsuneki H, Klink R, Lena C, Korn H, Changeux JP. Calcium mobilization elicited by two types of nicotinic acetylcholine receptors in mouse substantia nigra pars compacta. Eur J Neurosci 2000; 12: 2475-85.

13 Sharma G, Vijayaraghavan S. Nicotinic cholinergic signaling in hippocampal astrocytes involves calcium-induced calcium release from intracellular stores. Proc Natl Acad Sci USA 2001; 98: 414853.

14 Dajas-Bailador FA, Mogg AJ, Wonnacott S. Intracellular $\mathrm{Ca}^{2+}$ signals evoked by stimulation of nicotinic acetylcholine receptors in SH-SY5Y cells: contribution of voltage-operated $\mathrm{Ca}^{2+}$ channels and $\mathrm{Ca}^{2+}$ stores. J Neurochem 2002; 81: 606-14.

15 Gueorguiev VD, Zeman RJ, Meyer EM, Sabban EL. Involvement of alpha7 nicotinic acetylcholine receptors in activation of tyrosine hydroxylase and dopamine beta-hydroxylase gene expression in PC12 cells. J Neurochem 2000; 75: 1997-2005.

16 Lassignal NL, Martin AR. Effect of acetylcholine on postjunctional membrane permeability in eel electroplaque. J Gen Physiol 1977; $70: 23-36$.

17 Lewis CA. Ion-concentration dependence of the reversal potential and the single channel conductance of ion channels at the frog neuromuscular junction. J Physiol 1979; 286: 417-45.

18 Grynkiewicz G, Poenie M, Tsien RY. A new generation of $\mathrm{Ca}^{2+}$ indicators with greatly improved fluorescence properties. J Biol Chem 1985; 260: 3440-50.

19 Zhou Z, Neher E. Calcium permeability of nicotinic acetylcholine receptor channels in bovine adrenal chromaffin cells. Pflugers Arch 1993; 425: 511-7.

20 Neher E. The use of fura-2 for estimating Ca buffers and Ca fluxes. Neuropharmacology 1995; 34: 1423-42.

21 Fucile S, Renzi M, Lax P, Eusebi F. Fractional $\mathrm{Ca}^{2+}$ current through human neuronal alpha7 nicotinic acetylcholine receptors. Cell
Calcium 2003; 34: 205-9.

22 Gerzanich V, Wang F, Kuryatov A, Lindstrom J. alpha5 Subunit alters desensitization, pharmacology, $\mathrm{Ca}^{2+}$ permeability and $\mathrm{Ca}^{2+}$ modulation of human neuronal alpha3 nicotinic receptors. J Pharmacol Exp Ther 1998; 286: 311-20.

23 Tapia L, Kuryatov A, Lindstrom J. $\mathrm{Ca}^{2+}$ permeability of the (alpha4)3(beta2)2 stoichiometry greatly exceeds that of (alpha4)2(beta2)3 human acetylcholine receptors. Mol Pharmacol 2007; 71: 769-76.

24 Shoop RD, Chang KT, Ellisman MH, Berg DK. Synaptically driven calcium transients via nicotinic receptors on somatic spines. J Neurosci 2001; 21: 771-81.

25 Barrantes GE, Murphy CT, Westwick J, Wonnacott S. Nicotine increases intracellular calcium in rat hippocampal neurons via voltage-gated calcium channels. Neurosci Lett 1995; 196: 101-4.

26 Vijayaraghavan S, Pugh PC, Zhang ZW, Rathouz MM, Berg DK. Nicotinic receptors that bind alpha-bungarotoxin on neurons raise intracellular free $\mathrm{Ca}^{2+}$. Neuron 1992; 8: 353-62.

27 Mulle C, Choquet D, Korn H, Changeux JP. Calcium influx through nicotinic receptor in rat central neurons: its relevance to cellular regulation. Neuron 1992; 8: 135-43.

28 Berridge MJ, Bootman MD, Roderick HL. Calcium signalling: dynamics, homeostasis and remodelling. Nat Rev Mol Cell Biol 2003; 4: 517-29.

29 Eberhard DA, Holz RW. Cholinergic stimulation of inositol phosphate formation in bovine adrenal chromaffin cells: distinct nicotinic and muscarinic mechanisms. J Neurochem 1987; 49: 1634-43.

30 Yang J, McBride S, Mak DO, Vardi N, Palczewski K, Haeseleer F, et al. Identification of a family of calcium sensors as protein ligands of inositol trisphosphate receptor $\mathrm{Ca}^{2+}$ release channels. Proc Natl Acad Sci USA 2002; 99: 7711-6.

31 Murchison D, Griffith WH. Mitochondria buffer non-toxic calcium loads and release calcium through the mitochondrial permeability transition pore and sodium/calcium exchanger in rat basal forebrain neurons. Brain Res 2000; 854: 139-51.

32 Arnaudeau S, Kelley WL, Walsh JV, Jr., Demaurex N. Mitochondria recycle $\mathrm{Ca}(2+)$ to the endoplasmic reticulum and prevent the depletion of neighboring endoplasmic reticulum regions. J Biol Chem 2001; 276: 29430-9.

33 Malli R, Frieden M, Trenker M, Graier WF. The role of mitochondria for $\mathrm{Ca}^{2+}$ refilling of the endoplasmic reticulum. J Biol Chem 2005; 280: 12114-22.

34 Graier WF, Frieden M, Malli R. Mitochondria and $\mathrm{Ca}^{2+}$ signaling: old guests, new functions. Pflugers Arch 2007; 455: 375-96.

35 Rizzuto R, Pozzan T. Microdomains of intracellular $\mathrm{Ca}^{2+}$ : molecular determinants and functional consequences. Physiol Rev 2006; 86: 369-408.

36 Ferroni S, Marchini C, Ogata T, Schubert P. Recovery of deficient cholinergic calcium signaling by adenosine in cultured rat cortical astrocytes. J Neurosci Res 2002; 68: 615-21.

37 Rui Y, Tiwari P, Xie Z, Zheng JQ. Acute impairment of mitochondrial trafficking by beta-amyloid peptides in hippocampal neurons. J Neurosci 2006; 26: 10480-7.

38 Kulak JM, McIntosh JM, Yoshikami D, Olivera BM. Nicotineevoked transmitter release from synaptosomes: functional association of specific presynaptic acetylcholine receptors and voltagegated calcium channels. J Neurochem 2001; 77: 1581-9. 
39 Zoli M, Moretti M, Zanardi A, McIntosh JM, Clementi F, Gotti C. Identification of the nicotinic receptor subtypes expressed on dopaminergic terminals in the rat striatum. J Neurosci 2002; 22: 8785-9.

40 Soliakov L, Wonnacott S. Voltage-sensitive $\mathrm{Ca}^{2+}$ channels involved in nicotinic receptor-mediated $\left[{ }^{3} \mathrm{H}\right]$ dopamine release from rat striatal synaptosomes. J Neurochem 1996; 67: 163-70.

41 Gray R, Rajan AS, Radcliffe KA, Yakehiro M, Dani JA. Hippocampal synaptic transmission enhanced by low concentrations of nicotine. Nature 1996; 383: 713-6.

42 Sharma G, Vijayaraghavan S. Modulation of Presynaptic Store Calcium Induces Release of Glutamate and Postsynaptic Firing. Neuron 2003; 38: 929-39.

43 Wonnacott S. Presynaptic nicotinic ACh receptors. Trends Neurosci 1997; 20: 92-8.

44 Soliakov L, Wonnacott S. Involvement of protein kinase $\mathrm{C}$ in the presynaptic nicotinic modulation of $\left[{ }^{3} \mathrm{H}\right]$-dopamine release from rat striatal synaptosomes. Br J Pharmacol 2001; 132: 785-91.

45 Cox ME, Parsons SJ. Roles for protein kinase C and mitogenactivated protein kinase in nicotine-induced secretion from bovine adrenal chromaffin cells. J Neurochem 1997; 69: 1119-30.

46 Delouche B, Pradel LA, Henry JP. Phosphorylation by protein kinase $\mathrm{C}$ of annexin 2 in chromaffin cells stimulated by nicotine. $\mathrm{J}$ Neurochem 1997; 68: 1720-7.

47 Giniatullin R, Nistri A, Yakel JL. Desensitization of nicotinic ACh receptors: shaping cholinergic signaling. Trends Neurosci 2005; 28: 371-8.

48 Khiroug L, Giniatullin R, Klein RC, Fayuk D, Yakel JL. Functional mapping and $\mathrm{Ca}^{2+}$ regulation of nicotinic acetylcholine receptor channels in rat hippocampal CA1 neurons. J Neurosci 2003; 23: 9024-31.

49 Khiroug L, Giniatullin R, Sokolova E, Talantova M, Nistri A. Imaging of intracellular calcium during desensitization of nicotinic acetylcholine receptors of rat chromaffin cells. Br J Pharmacol 1997; 122: 1323-32.

50 Khiroug L, Sokolova E, Giniatullin R, Afzalov R, Nistri A. Recovery from desensitization of neuronal nicotinic acetylcholine receptors of rat chromaffin cells is modulated by intracellular calcium through distinct second messengers. J Neurosci 1998; 18 : 2458-66.

51 Liu Q Berg DK. Actin filaments and the opposing actions of CaM kinase II and calcineurin in regulating alpha7-containing nicotinic receptors on chick ciliary ganglion neurons. J Neurosci 1999; 19: 10280-8.

52 Greenberg ME, Ziff EB, Greene LA. Stimulation of neuronal acetylcholine receptors induces rapid gene transcription. Science 1986; 234: 80-3.

53 Dunckley T, Lukas RJ. Nicotine modulates the expression of a diverse set of genes in the neuronal SH-SY5Y cell line. J Biol Chem 2003; 278: 15633-40.

54 Mermelstein PG, Bito H, Deisseroth K, Tsien RW. Critical dependence of cAMP response element-binding protein phosphorylation on L-type calcium channels supports a selective response to EPSPs in preference to action potentials. J Neurosci 2000; 20: 266-73.

55 Hardingham GE, Arnold FJ, Bading H. Nuclear calcium signaling controls CREB-mediated gene expression triggered by synaptic activity. Nat Neurosci 2001; 4: 261-7.
56 Deisseroth K, Bito H, Tsien RW. Signaling from synapse to nucleus: postsynaptic CREB phosphorylation during multiple forms of hippocampal synaptic plasticity. Neuron 1996; 16: 89101.

57 Bito H, Takemoto-Kimura S. $\mathrm{Ca}^{2+} / \mathrm{CREB} / \mathrm{CBP}$-dependent gene regulation: a shared mechanism critical in long-term synaptic plasticity and neuronal survival. Cell Calcium 2003; 34: 425-30.

58 Bito $\mathrm{H}$. The role of calcium in activity-dependent neuronal gene regulation. Cell Calcium 1998; 23: 143-50.

59 Pelto-Huikko M, Dagerlind A, Kononen J, Lundberg JM, Villar M, Koistinaho J, et al. Neuronal regulation of c-fos, c-jun, and junB immediate-early genes in rat adrenal medulla. J Neurosci 1995; 15: 1854-68.

60 Salminen O, Seppa T, Gaddnas H, Ahtee L. The effects of acute nicotine on the metabolism of dopamine and the expression of Fos protein in striatal and limbic brain areas of rats during chronic nicotine infusion and its withdrawal. J Neurosci 1999; 19: 814551.

61 Chang KT, Berg DK. Voltage-gated channels block nicotinic regulation of CREB phosphorylation and gene expression in neurons. Neuron 2001; 32: 855-65.

62 Kumer SC, Vrana KE. Intricate regulation of tyrosine hydroxylase activity and gene expression. J Neurochem 1996; 67: 443-62.

63 Gueorguiev VD, Zeman RJ, Hiremagalur B, Menezes A, Sabban EL. Differing temporal roles of $\mathrm{Ca}^{2+}$ and cAMP in nicotine-elicited elevation of tyrosine hydroxylase mRNA. Am J Physiol 1999; 276: C54-65.

64 Griffiths J, Marley PD. $\mathrm{Ca}^{2+}$-dependent activation of tyrosine hydroxylase involves MEK1. Neuroreport 2001; 12: 2679-83.

65 Levin ED, Simon BB. Nicotinic acetylcholine involvement in cognitive function in animals. Psychopharmacology (Berl) 1998; 138: 217-30.

66 Sweatt JD. The neuronal MAP kinase cascade: a biochemical signal integration system subserving synaptic plasticity and memory. J Neurochem 2001; 76: 1-10.

67 Nestler EJ. Common molecular and cellular substrates of addiction and memory. Neurobiol Learn Mem 2002; 78: 637-47.

68 Nakayama H, Numakawa T, Ikeuchi T, Hatanaka H. Nicotineinduced phosphorylation of extracellular signal-regulated protein kinase and CREB in PC12h cells. J Neurochem 2001; 79: 489-98.

69 Dajas-Bailador FA, Soliakov L, Wonnacott S. Nicotine activates the extracellular signal-regulated kinase $1 / 2$ via the alpha7 nicotinic acetylcholine receptor and protein kinase A, in SH-SY5Y cells and hippocampal neurones. J Neurochem 2002; 80: 520-30.

$70 \mathrm{Hu}$ M, Liu QS, Chang KT, Berg DK. Nicotinic regulation of CREB activation in hippocampal neurons by glutamatergic and nonglutamatergic pathways. Mol Cell Neurosci 2002; 21: 616-25.

71 Mansvelder HD, McGehee DS. Long-term potentiation of excitatory inputs to brain reward areas by nicotine. Neuron 2000; 27: 349-57.

72 Ji D, Lape R, Dani JA. Timing and location of nicotinic activity enhances or depresses hippocampal synaptic plasticity. Neuron 2001; 31: 131-41.

73 Dani JA, Ji D, Zhou FM. Synaptic plasticity and nicotine addiction. Neuron 2001; 31:349-52.

74 Placzek AN, Dani JA. Synaptic plasticity within midbrain dopamine centers contributes to nicotine addiction. Nebr Symp Motiv 2009; 55: 5-15. 
75 Di Chiara G, Imperato A. Drugs abused by humans preferentially increase synaptic dopamine concentrations in the mesolimbic system of freely moving rats. Proc Natl Acad Sci USA 1988; 85: 5274-8.

76 Pidoplichko VI, DeBiasi M, Williams JT, Dani JA. Nicotine activates and desensitizes midbrain dopamine neurons. Nature 1997; 390: 401-4.

77 Laviolette SR, van der Kooy D. The neurobiology of nicotine addiction: bridging the gap from molecules to behaviour. Nat Rev Neurosci 2004; 5: 55-65.

78 Pandey SC, Roy A, Xu T, Mittal N. Effects of protracted nicotine exposure and withdrawal on the expression and phosphorylation of the CREB gene transcription factor in rat brain. J Neurochem 2001; 77: 943-52.

79 Brunzell DH, Russell DS, Picciotto MR. In vivo nicotine treatment regulates mesocorticolimbic CREB and ERK signaling in C57Bl/6J mice. J Neurochem 2003; 84: 1431-41.

80 Barrot M, Olivier JD, Perrotti LI, DiLeone RJ, Berton O, Eisch AJ, et al. CREB activity in the nucleus accumbens shell controls gating of behavioral responses to emotional stimuli. Proc Natl Acad Sci USA 2002; 99: 11435-40.

81 O'Neill MJ, Murray TK, Lakics V, Visanji NP, Duty S. The role of neuronal nicotinic acetylcholine receptors in acute and chronic neurodegeneration. Curr Drug Targets CNS Neurol Disord 2002; 1: 399-411.

82 Donnelly-Roberts DL, Xue IC, Arneric SP, Sullivan JP. In vitro neuroprotective properties of the novel cholinergic channel activator (ChCA), ABT-418. Brain Res 1996; 719: 36-44.

83 Dajas-Bailador FA, Lima PA, Wonnacott S. The alpha7 nicotinic acetylcholine receptor subtype mediates nicotine protection against NMDA excitotoxicity in primary hippocampal cultures through a $\mathrm{Ca}^{2+}$ dependent mechanism. Neuropharmacology 2000; 39: 2799-807.

84 Ferchmin PA, Perez D, Eterovic VA, de Vellis J. Nicotinic receptors differentially regulate $N$-methyl- $D$-aspartate damage in acute hippocampal slices. J Pharmacol Exp Ther 2003; 305: 1071-8.
85 Prendergast MA, Harris BR, Mayer S, Holley RC, Hauser KF, Littleton JM. Chronic nicotine exposure reduces $N$-methyl- $D$ aspartate receptor-mediated damage in the hippocampus without altering calcium accumulation or extrusion: evidence of calbindinD28K overexpression. Neuroscience 2001; 102: 75-85.

86 Wang XQ, Peng YP, Lu JH, Cao BB, Qiu YH. Neuroprotection of interleukin- 6 against NMDA attack and its signal transduction by JAK and MAPK. Neurosci Lett 2009; 450: 122-6.

87 Mandir AS, Poitras MF, Berliner AR, Herring WJ, Guastella DB, Feldman A, et al. NMDA but not non-NMDA excitotoxicity is mediated by poly(ADP-ribose) polymerase. J Neurosci 2000; 20: 8005-11.

88 Stevens TR, Krueger SR, Fitzsimonds RM, Picciotto MR. Neuroprotection by nicotine in mouse primary cortical cultures involves activation of calcineurin and L-type calcium channel inactivation. J Neurosci 2003; 23: 10093-9.

89 Shen JX, Tu B, Yakel JL. Inhibition of alpha7-containing nicotinic ACh receptors by muscarinic M1 ACh receptors in rat hippocampal CA1 interneurons in slices. J Physiol 2009; 587: 1033-42.

90 Quick MW, Lester RA. Desensitization of neuronal nicotinic receptors. J Neurobiol 2002; 53: 457-78.

91 Agulhon C, Petravicz J, McMullen AB, Sweger EJ, Minton SK, Taves SR, et al. What is the role of astrocyte calcium in neurophysiology? Neuron 2008; 59: 932-46.

92 Barres BA. The mystery and magic of glia: a perspective on their roles in health and disease. Neuron 2008; 60: 430-40.

93 Pavlov VA, Parrish WR, Rosas-Ballina M, Ochani M, Puerta $\mathrm{M}$, Ochani $\mathrm{K}$, et al. Brain acetylcholinesterase activity controls systemic cytokine levels through the cholinergic anti-inflammatory pathway. Brain Behav Immun 2009; 23: 41-5.

94 Gallowitsch-Puerta M, Tracey KJ. Immunologic role of the cholinergic anti-inflammatory pathway and the nicotinic acetylcholine alpha7 receptor. Ann N Y Acad Sci 2005; 1062: 209-19.

95 Wang H, Yu M, Ochani M, Amella CA, Tanovic M, Susarla S, et al. Nicotinic acetylcholine receptor alpha7 subunit is an essential regulator of inflammation. Nature 2003; 421: 384-8. 